\title{
中国式片屋根温室の日射透過特性 に関する模型実験
}

\author{
李 書民・蔵田憲次・高倉 直 \\ (東京大学農学部)
}

\author{
Scale-model Experiments on Solar Radiation Transmissivity \\ into a Chinese Style Lean-to Greenhouse \\ Shumin Li, Kenji Kurata and Tadashi Takakura \\ (Faculty of Agriculture, University of Tokyo, \\ ( Yayoi 1-1-1, Bunkyo-ku, Tokyo, 113 Japan
}

\begin{abstract}
Some experimental results of solar radiation transmissivity into a Chinese-style lean-to greenhouse were described. The greenhouse is east-west oriented and its north wall, north roof and east- and west-gable walls were made of opaque materials.

A scale-model greenhouse with the floor area of $20 \mathrm{~cm}$ (width) $\times 160 \mathrm{~cm}$ (length) was constructed and 16 solar cells (each detecting area is $11 \mathrm{~mm} \times 17.5 \mathrm{~mm}$ ) were set on the floor at its central part. Experimental observations were conducted from December 1992 to June 1993 in Tokyo $\left(35^{\circ} 41^{\prime} \mathrm{N}\right)$ at an interval of about 45 days on fine days as well as on overcast days. The results on fine days showed that in winter and spring daily transmissivity distributions on the floor were quite uniform except for some low radiation points due to shades of the purlines. In summer time, on the other hand, daily transmissivity at the north part of the greenhouse showed remarkably lower values compared to those of the rest part. Transmissivities during 9:00-15:00 were higher than those during the early or late hours of the day in every season. The results on an overcast day showed that diffuse radiation transmissivity on the floor was quite nonuniform because of the shade effect of the north wall and north roof to the diffuse radiation.

Key words: Diffuse radiation, Lean-to greenhouse, Scale-model greenhouse, Solar radiation, Transmissivity.

キーワード：片屋根温室, 天空日射, 透過率, 日射, 模型温室
\end{abstract}

\section{1.はじめに}

温室内へ透過した日射量とその分布は温室設計や温室 栽培で考慮しなければならない重要な因子である。それ らは温室内の気温, 湿度などの環境条件に影響を与える とともに，直接作物の光合成とも深く関連しており，最 終的には, 温室栽培の経済性にも大きく影響すると考え られる。

いままでに, 温室内の日射環境特性に関する研究は数 多くあるが, ほとんどの研究は両屋根式温室（単棟ある いは連棟)についてのあので(例えば, 古在, 1970,1974;

1994 年 6 月 8 日 全国大会にて発表

1994 年 3 月 24 日 受付, 1994 年 10 月 3 日 受理
古在・杉, 1972 ; 蔵田, 1983 ; Kurata, 1990；Critten, $1983 \mathrm{a}, \mathrm{b}$ ), 中国で普及している “単屋面温室”(片屋 根温室に相当する中国語）内に掞ける日射環境の解析は 少ない。わずかに吳毅明ら (1992)及び孫忠富ら (1993) がこの型の温室内の直達日射透過特性に関する数値計算 を行っているが, 冬季に室内の異なる部位（床面, 北側 の側壁・屋根の内側）における直達日射の日積算量の分 布を算出したに過ぎない。

“単屋面温室” は中国で園芸作物, 特に野菜作物の栽 培に広く応用されている温室の形態であり, 近年, 中国 の華北, 西北及び東北地方に数多く建てられている。乙 の型の温室は全て東西単棟温室であり，Fig. 1 亿示した ように, 北側の側壁と屋根 (以後, それぞれ裏壁, 裹屋 
根と呼ぶ）および東西両妻は不 透明の棟瓦, 土, 木材などで, 南側の屋根 (以後, 採光屋根之 呼ぶ）は透明なビニルフィルム である。夜間にはこの透明被覆 材の上に厚さ $2-3 \mathrm{~cm}$ のずれ などをかける。したがって，乙 の種類の温室は保温性が比較的 よく, 建築費む安く, 冬季に晴 天日の多い大陸性気候地域では, 無暖房でむ,トマト, キュウリ などの果菜類を栽培できる。乙 のように, “単屋面温室” は省 エネルギー的であり, また実用 性が高いなどの特長がある。以 後, 本報告では, 乙の中国語で “単屋面温室”之呼ばれる温室を単に片屋根温室と呼ぶ。 片屋根温室の構造は, 地区によって多少異なるが, 一 般的に, 間口が $6 \mathrm{~m}$, 棟高が $2.5 \sim 3 \mathrm{~m}$, 裹壁の高さが 1.6 2 $\mathrm{m}$ であり, 南側の採光屋根がアーチ形の曲面か平 面の組み合わせである。Fig.1 は後者の例である。普通, 棟の位置 (Fig.1ではRで示した) より北側は通路として 使われ，それより南側が栽培に使われる。

片屋根温室の構造上の特性は室内の微気候の特性と深 く関係していると思われるが，ての点関する研究例は ほとんどない。より一層効率的にての種類の温室を利用 し，生産性を向上させるためには，その日射透過特性の 究明が一つの課題である。

これまでの両屋根式温室の日射透過特性に関する研究 の大部分は理論モデルによる数值計算で, 実測による解 析例は少ない。例えば，温室やトンネル内での実測例で は, Critten (1985); Cave and Cockshull (1989); Kurata et al. (1991)などの研究が挙げられ, 模型温室 内での実測例では黒住・川島 (1977) などの研究が挙げ られる。また, スリークオーター温室内での実測例では 岩崎・木村 (1975) の研究, スリークオーター温室に近 い非対称性断面温室内での実測例ではWhittle and Lawrence (1959)などの研究が挙げられる。

上述したように，温室内の日射透過特性を解明するた めの手法として, 理論モデルによる数值解析, 実際の温 室内の観測之模型温室内の観測の 3 つが挙げられる。本 研究で, 対象にしている温室は日本には存在せず, 実際 の温室内で観測を行うことは不可能である。そてで, 代 表的構造の片屋根温室を対象として, 模型実験之数值計 算との 2 つの側面から, その日射透過特性を明らかにす るととを目的とした。本報では模型実験による結果を報
告する。

\section{2. 方 法}

\section{1 実験方法}

想定した供試温室の構造とその模型（比率 $1: 30$ ) のサ イズはTable 1 に，横断面図はFig.1亿それぞれ示した。 光センサーとしては, 太陽電池（ほくさん, 型番 S S 145B）を用いた。模型温室の床面の中央部に16個の太陽 電池を取り付けた。乙れらの太陽電池の受光面と床面之 の間の距離は $0.4 \mathrm{~cm}$ (実際の温室で, 地上 $0.12 \mathrm{~m}$ に相当) である。屋外の日射量は全天日射計（英弘精機産業， MS -4 型)で観測した。太陽電池のサイズは約幅 $11 \mathrm{~mm}$ ×長さ $17.5 \mathrm{~mm}$ である。太陽電池扰よび全天日射計の電 圧出力はハイブリットレコーダ(横河電機, Model 3081) により記録した。太陽電池は模型温室内に取り付ける前 に, 晴天日条件下で, 全天日射計の出力を基準としてキ ヤリブレーションした。

模型温室の床面および不透明の裏屋根, 裏壁と東西両 妻壁の内側をツヤ消しペンキで黒く塗り, 日射の反射の

Table 1 Structural parameters of the lean-to greenhouse.

\begin{tabular}{lll}
\hline & Actual & $\begin{array}{c}\text { Model } \\
(1 / 30)\end{array}$ \\
\hline Ridge height & $2.60 \mathrm{~m}$ & $8.7 \mathrm{~cm}$ \\
Width & $6.00 \mathrm{~m}$ & $20.0 \mathrm{~cm}$ \\
Length & $48.00 \mathrm{~m}$ & $160.0 \mathrm{~cm}$ \\
Beams: diameter & $0.06 \mathrm{~m}$ & $0.2 \mathrm{~cm}$ \\
$\quad$ pitch & $3.00 \mathrm{~m}$ & $10.0 \mathrm{~cm}$ \\
Rafters: diameter & $0.025 \mathrm{~m}$ & $0.082 \mathrm{~cm}$ \\
$\quad$ pitch & $1.00 \mathrm{~m}$ & $3.3 \mathrm{~cm}$ \\
Purlins: diameter & $0.06 \mathrm{~m}$ & $0.2 \mathrm{~cm}$ \\
Orientation & $\mathrm{E}-\mathrm{W}$ & $\mathrm{E}-\mathrm{W}$ \\
\hline
\end{tabular}


Table 2 Date of measurement.

\begin{tabular}{lcc}
\hline & $\begin{array}{c}\text { Sunrise hour } \\
\text { angle }^{a}\end{array}$ & $\begin{array}{c}\text { Solar altitude } \\
\text { at culmination }\end{array}$ \\
\hline Dec. 22, 1992 & $-28.6^{\circ}$ & $30.9^{\circ}$ \\
Feb. 10, 1993 & $-17.3^{\circ}$ & $39.9^{\circ}$ \\
Mar. 23, 1993 & $+1.7^{\circ}$ & $55.2^{\circ}$ \\
Apr. 15, 1993 & $+12.5^{\circ}$ & $64.0^{\circ}$ \\
May 13, 1993 & $+23.3^{\circ}$ & $73.1^{\circ}$ \\
Jun. 5, 1993 & $+28.8^{\circ}$ & $76.9^{\circ}$ \\
\hline
\end{tabular}

${ }^{a} 0^{\circ}$ for east, positive northwards.

影響を少なくした。被覆材には塩化ビニルフィルムを用 い, 各観測日の前に張り替え, フィルムの劣化の影響を なくした。実験は周りの障害物の少ない東京大学農学部 4 号館(北緯 $35^{\circ} 41^{\prime}$ ) の屋上で以下に述べる日に行った。 晴天日の観測を Table 2 亿示した日に，曇天日の観測を 1993 年 6 月 5 日に行った。 Table 2 亿は各観測日の日 の出の方位角抢よび南中高度も示した。

\section{2 透過率の概念について}

本報告では，混同を避けるため次のように各透過率を 定義した。室内床面のある点, ある時刻の水平面日射量 と室外水平面日射量の比を透過率とする。ただし，曇天 日 (1993 年 6 月 5 日) の透過率は, 晴天日のそれと区別 するため天空日射透過率と呼ぶ。乙れは観測日の雲量が 10 で, 室外水平面に抢ける日積算日射量む $6.8 \mathrm{MJ} / \mathrm{m}^{2}$ 之低かったので，水平面日射量はほぼ $100 \%$ 天空日射か ら成り立っていると考えられたからである。また，栽培 面透過率は室内栽培床面 (床面の歩道以外の部分) に抢け る透過率の平均値を, 日透過率は室内のある点の一日の 積算日射量之室外のそれとの比を, 栽培面日透過率は室 内栽培床面に打ける日透過率の平均値を意味する。乙こ で，以上の各定義中の「ある点での日射量」とあるのは， 実際には上記の太陽電池による観測値を用いた。したが って, 本実験の観測結果は, 温室中央部の断面でのあの である。本模型温室(スパン: 長さ $=1: 8)$ のように細長 い温室では，太陽高度のごく低い時間帯を除いて，中央 部の透過率で全体の透過率を代表できるあのと考えられ る。

\section{3. 結果}

\section{1 晴天日観測結果}

Fig. 2 亿栽培面日透過率の季節变化を示す。12月と 2 月には 0.8 前後の高い值を示し, 季節の進行ととあに 低下し， 5 月には 0.63 となった。その主な理由は後で示 すように，夏季に近づくにつれ太陽高度が高くなり，裏 壁と裏屋根の遮蔽の影響が大きくなったからであると考 えられる。

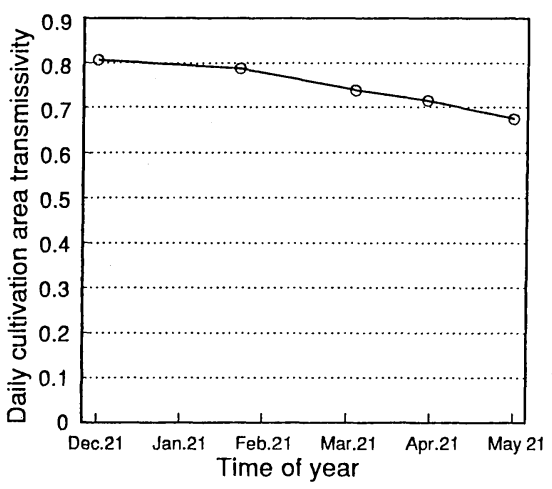

Fig. 2. Daily cultivation area transmissivities at different seasons on fine days.

Circles indicate the experiment dates.

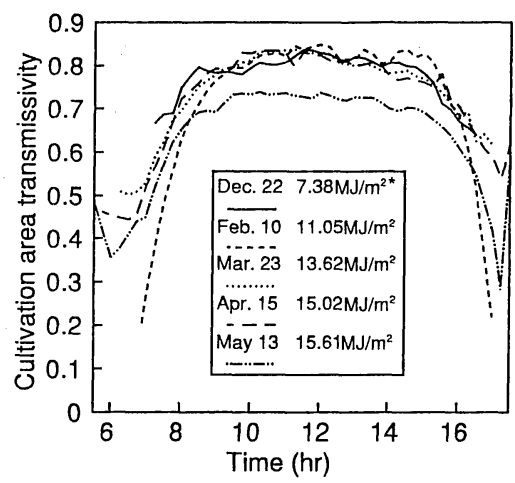

Fig. 3. Diurnal courses of cultivation area transmissivity at different seasons on fine days.

* Values indicate the daily integrals of solar radiation averaged over the floor of the greenhouse.

Fig. 3 亿栽培面透過率の時間変化・季節変化を示した。 時刻は中央標準時である。季節にかかわらず栽培面透過 率は昼でろには高く，早朝と夕方には低い。また，午前 9:00 ごろから午後 $15: 00$ ごろまで栽培面透過率の変化 は少ないととがわかった。正午前後の栽培面透過率は 12 月〜 4 月で大体同じであるが， 5 月はそれよりも低下し た。日の出と日没でろの栽培面透過率は季節によって異 なる值を示した。

Fig. 4 に床面に掯ける日透過率分布の季節ごとの変動 の様子を示した。冬, 春季における日透過率分布は比較 的均一であるが， 4,5 月では，不均一になった。特に， 4, 5 月には裏壁の近くの点の日透過率が大きく低下する のが特徴的である。また，季節によって位置が異なるが， 明らかに母屋の影の影響とみられる日透過率の低い場所 があるととがわかった。12月には裏壁から $14 \mathrm{~cm}$ ぐら い，2月には $15 \mathrm{~cm}$ ぐらいの位置にてれらの日透過率の 低い点が見られる。また， 12 月と 2 月には，床面の一 


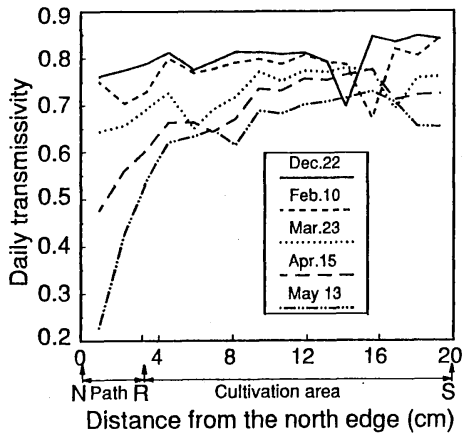

Fig. 4. Daily transmissivity distributions on the floor of the greenhouse at different seasons on fine days.

番南側に打ける約 $5 \mathrm{~cm}$ の範囲は高い日透過率となって いる。乙れは一番南側の屋根の傾斜角が大きく, 太陽光 線の被覆材への入射角が小さいからであると思われる。 全体的には, 冬季加夏季にかけて, 床面上各観測点に おける日透過率がだんだん低くなってくることがわかっ た。

Fig. 5 は床面における各時刻の透過率を示した。午後 の透過率は大体午前と対称であった。季節にかかわらず 昼頃の透過率が一番高く, 朝早くになるとともに透過率 が低くなった。母屋の影響とみられる透過率の低い点は 太陽高度の低い早朝には見られず, 昼に近づくにつれて 現れた。乙のように透過率の低くなる個所に 12 月以外 は 2 つある。乙れは模型温室の南屋根の 2 本の母屋に対 応している (Fig. 1)。12月には裏壁に近い母屋の影は 裏壁内側に投影された。また， 4 月と 5 月になると，床 面北側の歩道の範囲では, 一日のほとんどの時間帯で低 い透過率を示した。乙れは不透明な裏壁と裹屋根の影響 である。なお，Fig. 5 には，はりやたるきの影が太陽電 池に投影されたてとに起因する变動む含まれている点に 注意する必要がある（他の図では，乙の変動は空間的あ るいは時間的に平均化されている)。たとえば，北側か ら $5 \mathrm{~cm}$ 近辺の 12 時の透過率は 12 月のほうが 5 月より わずかながら大きい。しかし，直達日射の被覆材への入 射角から計算される透過率はほぼ等しいはずである。乙 れは，5月13日 12 時には，ほぼ北半分の太陽電池には りの影がかかっていたためである（ててでいう時刻は日 本標準時であり, 真太陽時ではない)。

\section{2 量天日観測結果}

天空日射透過率の分布をFig. 6 を示した。北の端から 南の端に向けて天空日射透過率が大きくなる傾向がある が，最高值は南の端から約 $5 \mathrm{~cm}$ の所にあった。栽培面 での平均天空日射透過率は 0.68 と低く, 不透明の裏壁と

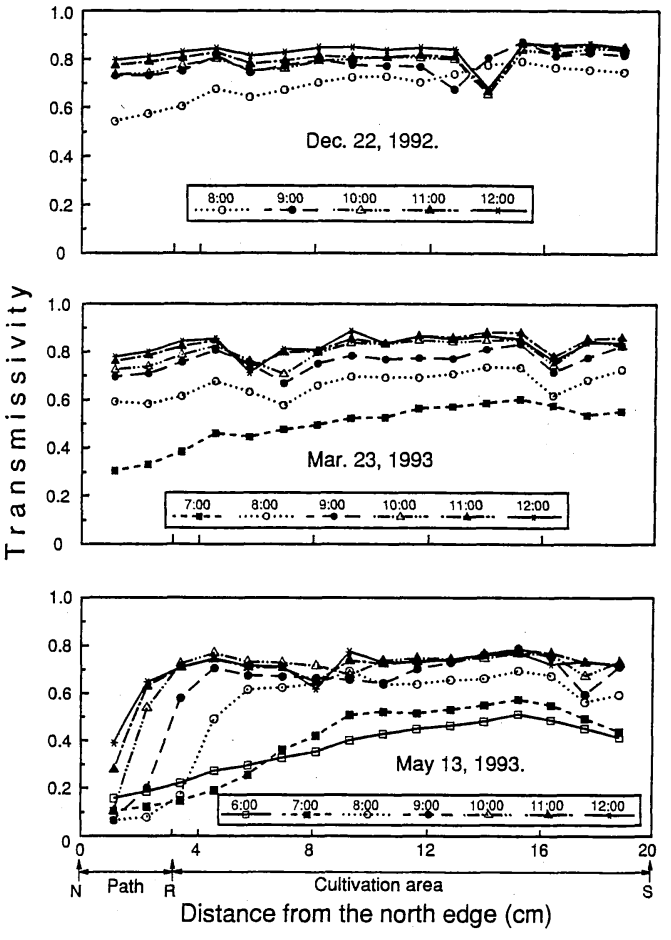

Fig. 5. Hourly variations of transmissivity on the floor of the greenhouse at different seasons on fine days.

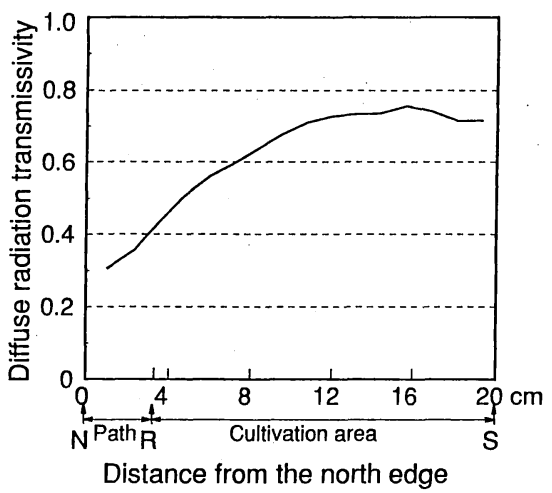

Fig. 6. Distribution of diffuse radiation transmissivity on the floor of the greenhouse (June 5, 1993).

裏屋根の天空日射透過率への影響が大きいととを示唆し ている。

\section{4. 考察}

以上の実測結果から明らかになった片屋根温室の日射 透過特性は東京地区の他, 同じ緯度を持つ中国の華北, 華中の隣接地区にあ参考之なると思われる。次に，てれ らの結果をてれまでに発表された東京やその周辺地区に 
関する東西単棟両屋根温室の日射透過特性の解析結果と 比べてみよう。

古在 (1974) の数值解析結果と黒住ら (1977) の模型 実験結果は, いずれむ南北棟温室と比較した場合, 東西 棟温室の有利性は冬季だけに限られ，春分になると，北 屋根への日射の入射角が大きくなり，床面の北側に弱光 帯を生じて，一日中床面に㧍ける日射透過率の分布がか なり不均一になるととを報告している。さらに，黒住ら （1977）の結果によると，屋根勾配 $30^{\circ}$ では床面北側 $1 / 5$ ほどの面積が弱光帯となり，他の部分より日透過率は約 $40 \%$ 少なく, 屋根勾配 $15^{\circ}$ では弱光帯の幅が北側 $1 / 3$ 之 広がり, 日透過率の減少は約 $15 \%$ となっている。本実験 では，冬季・晴天日条件下での結果は古在と黒住らのそ れと似ていて，床面における日透過率分布は比較的均一 であった。しかし，3月23日の結果は日透過率の最高, 最低値の差が約 $13 \%$ であり, 黒住らの結果ほど大きくな かった。黒住らは直達日射だけを対象にし，本実験では 全日射を対象にしているてとあ関係しているが，ての違 いの大きな原因は温室の構造の違いにあると推論できる。 すなわち, 片屋根温室では床面全体の南側から $5 / 6$ の真 上は全部南向の透明屋根であり, 両屋根温室の弱光帯の 原因となった北屋根の部分が少ないてとが関係している と考えられる。乙の様に, 晴天日条件下で, 片屋根温室 は冬, 春季とあ床面に打ける日透過率分布が比較的均一 である。一方, 片屋根温室内天空日射透過率の分布 (Fig. 6)をKurata (1990) の両屋根単棟温室の解析結果之比 較すると北側部分における低下が激しく, 不均一性が増 大しているてとが明らかとなった。

母屋の影の影響は黒住ら（1977）の模型実験結果や古 在 (1974) の計算結果之同じく, 明らかに低透過率の個 所を生じた。ただし, 本実験の結果では, 古在の結果ほ ど母屋の影の部分の日透過率の低下は見られなかった。 乙れは本実験は直達日射と天空日射が併存する場合の解 析であるのに対して, 古在のは直達日射条件だけを対象 としたあのであるからと考えられる。なお, 本実験の各 季節に书ける時刻別の栽培面透過率变化の結果は古在や 黒住らの結果と似て, 朝夕には低く, 正午前後には高い 值を示した。

\section{5. 結論}

模型温室を用いた東京での観測から, 中国式片屋根温 室の日射透過特性を明らかにした。その結果, 片屋根温 室では冬季だけではなく春季にも栽培面床面の透過率の 均一性が高いとと, 夏季には, ちょうど北側の通路の部 分の透過率が低下するとと, 天空日射の透過率は北側ほ
ど低くなり，不均一性が著しいととなどの特徵が明らか となった。

\section{引用文献}

Cave, C. R. J. and Cockshull, K. E., 1989: The effect of using a venetian reflector assembly to improve winter light levels in a single-span glasshouse on the growth of a pot chrysanthemum crop. Solar Energy, 42 (4), 319-325.

Critten, D. L., 1983a: A computer model to calculate the daily light integral and transmissivity of a greenhouse. J. Agric. Engng. Res., 28, 6167.

Critten, D. L., 1983b: The evaluation of a computer model to calculate the daily light integral and transmissivity of a greenhouse. J. Agric. Engng. Res., 28, 545-563.

Critten, D. L., 1985: The use of reflectors in venetian blinds to enhance irradiance in greenhouses. Solar Energy, 34 (1), 83-92.

岩崎正男・木村 進, 1975：施設園芸の微気象環境管理 に関する研究. 第 1 報. メロン栽培温室の微気象的特 性. 静岡農試研報, $20,33-40$.

古在豊樹, 1970 : 温室内の日射量飞関する研究 (1)。農 業気象, 26 (3), 123-130.

古在豊樹・杉 二郎, 1972 : 温室内の日射量に関する研 究 (2). 農業気象, 27 (3), 105-135.

古在豊樹, 1974 : 温室の光透過汇関する数値実験 (2).

農業気象, $29(4), 239-247$.

蔵田憲次, 1983 : 温室の光環境改善のための研究. (I) フレネルプリズムの温室被覆への応用．農業気象, 39 (2), 103-106.

Kurata, K., 1990: Role of reflection in light transmissivity of greenhouses. Agricultural and Forest Meteorology, 52, 319-331.

Kurata, K., Quan, Z. and Nunomura, O., 1991: Optimal shapes of parallel east-west oriented single-span tunnels with respect to direct light transmissivity. J. Agric. Engng. Res., 48, 89100.

黒住 徹・川島信彦, 1977 : 温室の光線透過㳊関する模 型実験 (第 1 報)：棟方位と屋根形状について, 奈良県 農業試験場研究報告, 第 8 号, 9-18.

孫 忠富 - 吳 毅民・曹 永華 - 李 佑祥, 1993 : 日光 温室中直射光的計算機模似方法. 一設施農業環境模似 分析研究之三 農業工程学報, 9 (1), 2-7.

Whittle, R. M. and Lawrence W. J. C., 1959: The climatology of glasshouses. I. Natural illumination. J. Agric. Engng. Res., 4, 326-340.

呉 毅明・曹 永華・孫 忠富 - 李 佑祥, 1992 : 温室 采光設計的理論分析方法. 一設施農業環境模似分析研 究之一. 農業工程学報, 8 (3), 73-80. 